\title{
Developing An Integrated Model of Failure Model and Three Stages Model in ERP Implementation
}

\author{
Michiko Miyamoto Shuhei Kudo \\ Department of Management Science and Engineering \\ Akita Prefectural University \\ Yurihonjo, Akita, JAPAN \\ \{miyamoto,s_kudo@akita-pu.ac.jp\}
}

\author{
Kayo Iizuka \\ School of Network and Information \\ Senshu University \\ Kawasaki, Kanagawa, JAPAN \\ iizuka@isc.senshu-u.ac.jp
}

\begin{abstract}
After analyzing the literature on IT failures, we have developed a failure model of ERP implementation with the system failure notions that defined by Saucer (1996) along with the Davis's three stages model (1974). A structural equation modeling (SEM) was used to test the framework with data from 266 ERP-user in Japan. The results imply the managerial implication for ERP vendors, such as lowering annual operating cost, maintenance fee, fees associated in interface systems, as well as improving vendor support will reduce some difficulties in ERP implementation.
\end{abstract}

Keywords- ERP failure, Three stages model, SEM

\section{INTRODUCTION}

The process of introducing the Enterprise Resource Planning (ERP) system is relatively complex and extremely risky, and implementation failures are sometimes reported [3][1]. About half of ERP implementations fail to meet expectations [21]. It is estimated that approximately $90 \%$ of enterprise system implementations are late or over budget [17]. The results of a number of implementation studies suggest that implementation failure is more likely when users hold unrealistic expectations about the system [13]. This is because ERP, by its very nature, imposes its own logic on a company's strategy, organization and culture [8]. Japanese companies might be more vulnerable to ERP failures because the reference process models underlying most ERP systems reflect European or US industry practices [23].

System development efforts can be viewed as multi-stage processes [13]. In management information system implementation, most of key decisions are made in preimplementation stage. These pre-implementation decisions will have the greatest effect on an assessment of the project's probability of success or failure should be possible at that time. The Soh and Markus framework describes the "IT investment to business value” process as a series of three linked models that correspond to the phases of a typical IT investment; system development, implementation, and ongoing operation [22]. The outcomes of one phase became starting conditions for the next. Thus, decisions and actions in a phase may increase or decrease the potential for success ("optimal success") subsequently. Furthermore, because each phase generally involves different groups of people, the framework directs attention to communication difficulties that accompany "the handoffs" from one phase to the next. Markus and Tanis [16] identify a new first phase, called chartering. The remaining three phases in the enterprise system experience cycle (the project phase, the shakedown phase, and the onward and upward phase) correspond to the three phases in the Soh and Markus model.

In this research, we develop a failure model of ERP implementation by different stages of ERP implementation. Lyytinen and Hirschheim identified 4 major categories of IS failure; correspondence failure, process failure, interaction failure and expectation failure [15]. Sauer's theory of failure emphasis on failure due to different perspectives from different users, it stresses the need to balance 3 keys factors; system, supporters and social organizations [20]. We utilize system failure notions that defined by Sauer [20]. As the Sauer' theory did not go through verification by data collection from those organizations which implemented ERP system, hence to achieve more valid evidence, this premise is examined via a survey of 266 ERP users from different companies in Japan.

\section{LITERATURE REVIEW}

\section{A. ERP Implementation and User Satisfaction}

The importance of user satisfaction in determining ERP projects' success has been stressed by many scholars and several frameworks were developed in order to evaluate the level of ERP users' satisfaction [7][19][26][14][12]. Calisir and Calisir [7] conducted a research aiming to better understand which factors influence ERP end-user satisfaction. Their framework measures six interface usability characteristics; system capability, compatibility, flexibility, user guidance, learnability, minimal memory load, and perceived usefulness, and perceived ease of use. Zviran, Pliskin, and Levin [27] examined the relations between user satisfaction and perceived usefulness in the ERP context.

Delone and McLean (D\&M) conducted an extensive literature review on 180 empirical studies published in six top IS journals and one of the most important IS conference proceedings [10]. D\&M classified dimensions of IS success into six categories; (1) System quality, (2) Information quality, (3) Information Use, (4) User satisfaction, (5) 
Individual impact, (6) Organizational impact. Later, D\&M have updated their original success model [11]. Miyamoto, Kudo, and Iizuka [18] analyze users' satisfactions come from operational efficiency, enhancement of management control and improve efficiency.

\section{B. Failure and Difficulties in ERP Implementation}

Process failure concerns two different kinds of problems. The first is that a planned information system is not workable at all, often due to difficulties or irresolvable problems in designing, implementing or configuring the IS. Other problems concern that the IS cannot be produced within the given budget or time schedule. Furthermore, this overspending leads to limitation of the benefits of the system. Interaction failure deals with the idea that a low level of use of an IS can be considered to be the same as an IS failure. Studies in this field concern user's interaction with IS, user attitudes and user satisfaction. It implies that if the user uses the IS to a high degree in the way the system is intended to be used, s/he is satisfied with it, attitudes are positive and the task performance is improved. Expectation failure is inability of an IS to meet a specific stakeholder group's expectations. Lyytinen and Hirschheim argue that stakeholders' interests are formulated through a number of expectations, that is the beliefs and desires on how the IS will serve the group's interest [15].

Sauer [20] develops a model of three main components: the information system, project organization and its supporters. An information system exists to produce information and/or to support or automate the work performed by other work system. An information system must serve some organizational stakeholders and thereby function as a resource for the project organization in gathering support. A project organization is simply that group of people who at a particular point in time are occupied with the development, operation or maintenance of a given information system. Supporters are those who actually provide support to projects and require benefits from the information system. Sauer claims this "triangle of dependencies" model can be used for explaining the failure of a given information system [20].

Failure occurs when the level of dissatisfaction of supporters with a system rises to the extent when there is no longer enough support to sustain it. Problems in any of these three relationships will be the source of consequential difficulties for the other two, and unless the problems can be solved, this will lead ultimately to total withdrawal of support and system failure.

\section{RESEARCH MODEL AND HYPOTHESES}

The aim of the research is to develop a framework, based on Failure Model of Sauer [20] along with the Davis's three stages model [9], which can be used to identify the critical failure factors of ERP implementation in different phases as shown in figure 1 . This framework will be applied to investigate the failure of the ERP implementation in Japan. Davis suggests a conceptualization of the three stages of system development [9]. The first of the stages is Definition, where most of the key decisions about the system as the user will see it are made, e.g., system goals, scope, overall approach [13]. Then, the second is the physical design stage, which includes system design, program development, and procedure development. We call this stage as "Design and Development Phase." The third, and the final stage is the Implementation stage, which includes conversion operation, maintenance, and post audit. We define the final stage as "ERP Implementation Phase."

We introduce latent variables based on the properties of the questionnaire as follows; (1) Information System, (2) Project Supporter, and (3)Project Organization, and (4) Difficulties found in different phases, such as (a) definition phase, (b) design and development phase, and (c) ERP implementation phase. In each phase, there are several steps, from an early step to a final step.

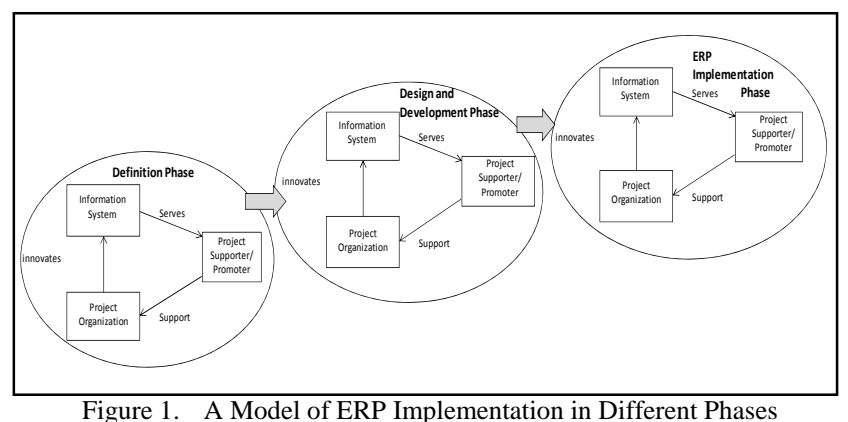

Therefore, the following hypotheses are proposed, and are examined by three different phases of ERP implementation.

D-1 Definition Phase

H-1: Difficulties in Information System will affect Project Supporter.

H-2: Difficulties in Project Supporter will affect Project Organization.

H-3: Project Organization will affect Information System.

H-4: Difficulties in Information System will affect each of Definition Phase.

H-5: Difficulties in Project Supporter will affect each of Definition Phase.

H-6: Project Organization will affect each of Definition Phase.

D-2 Design and Development Phase

$\mathrm{H}-1$ : Difficulties in Information System will affect Project Supporter.

H-2: Difficulties in Project Supporter will affect Project Organization.

H-3: Project Organization will affect Information System.

H-4: Difficulties in Information System will affect each of Design and Development Phase.

H-5: Difficulties in Project Supporter will affect each of Design and Development Phase. 
H-6: Project Organization will affect each of Design and Development Phase.

\section{D-3 ERP Implementation Phase}

H-1: Difficulties in Information System will affect Project Supporter.

H-2: Difficulties in Project Supporter will affect Project Organization.

H-3: Project Organization will affect Information System.

H-4: Difficulties in Information System will affect each of ERP Implementation Phase.

H-5: Difficulties in Project Supporter will affect each of ERP Implementation Phase.

H-6: Project Organization will affect each of ERP Implementation Phase.

\section{A. Data}

\section{SURVEYS}

Data were collected through a survey conducted by IT Leaders and ERP Forum Japan ${ }^{1}$ in May, 2011. They amassed 266 valid responses. The survey was conducted in the form of a web questionnaire, and respondents were solicited via an e-mail magazine to readers of IT Leaders. This data can conceivably be valuable since the respondents concerned are individuals with awareness of IT issues.

Most of the questionnaires are asked by 5 point scale. A list of sample size by different industry classification is shown in Table $\mathrm{I}^{2}$.

\section{B. Data Preparation}

We have a dataset containing eight failure related variables, such as "Gap", "No fit”, "Poor vendor support", "Maintenance fee” "Upgrading”, “Annual operating cost”, "Interface systems", and "Better package." Then, we create three latent variables such as "Information System," "Project Supporter" and "Project Organization," which represent those failure related variables. We also create one latent variable which represent different phases; Definition Phase, Design and Development Phase, and ERP Implementation Phase.

Table II contains the Pearson correlation coefficient between all pairs of eight failure related variables with the two-tailed significance of these coefficients. Although some relationships with "Better package" are not significant, most of the variables correlate fairly well and none of the

1 ERP Forum Japan is the only organization in Japan that is dedicated to studying ERP issues and solving related problems, founded in 1996 with 200 member companies, those consists of three categories; SI \& Consulting Firms, ERP, SCM, CRM Vendors, and IT Users. IT Leaders is a specialized magazine, which was first published in September 2008, and web site, providing the up-to-date information on IT products and technologies on enterprise information systems. It is published by the control circulation method, in which readers chosen from people preregistered can subscribe it at no charge, and has been currently subscribed by 30,000 readers in a month.

2 For more detailed descriptive analyses, see "ERP User Survey 2011 Executive Summary (English Version)” published by ERP Forum Japan [24]. correlation coefficients are particularly large; therefore, multicollinearity is not a problem for these data. We omit "Better package" from our analysis.

TABLE I. SAMPLE CHARACTERISTICS

\begin{tabular}{|c|c|c|c|}
\hline & & \begin{tabular}{|c|} 
Effective \\
data
\end{tabular} & $\begin{array}{l}\text { Percentage } \\
(\%)\end{array}$ \\
\hline \multirow[t]{5}{*}{ Industry Group } & Manufacturing and Construction & 136 & 51.13 \\
\hline & Distribution & 32 & 12.03 \\
\hline & Service & 45 & 16.92 \\
\hline & Information Services & 48 & 18.05 \\
\hline & Others & 5 & 1.88 \\
\hline \multirow[t]{5}{*}{ Size by Sales } & over one trillion yen & 13 & 4.90 \\
\hline & 100 billion $\sim$ one trillion yen & 55 & 20.60 \\
\hline & 30 billion $\sim 100$ billion yen & 43 & 16.10 \\
\hline & 5 billion $\sim 30$ billion yen & 89 & 33.40 \\
\hline & less than 5 billion yen & 66 & 24.80 \\
\hline \multirow[t]{5}{*}{ Size by Number of Employees } & less than 299 people & 66 & 24.81 \\
\hline & $300-999$ & 30 & 11.28 \\
\hline & $1,000-4,999$ & 22 & 8.27 \\
\hline & $5,000-9,999$ & 7 & 2.63 \\
\hline & over 10,000 & 9 & 3.38 \\
\hline Human resources and Payroll & erp_per & 60 & 22.6 \\
\hline Business process automation & erp_ope & 100 & 34.6 \\
\hline Accounting/Financial & erp_acc & 129 & 48.5 \\
\hline Enterprise sy stem & erp_main & 43 & 16.2 \\
\hline Total solution & erp_all & 42 & 15.8 \\
\hline Gap & $\begin{array}{l}\text { There is a gap in the current } \\
\text { business situation and the effect } \\
\text { gained by ERP implementation. }\end{array}$ & 32 & 12.0 \\
\hline No fit & $\begin{array}{l}\text { EPR does not meet the business } \\
\text { requirements of a company. }\end{array}$ & 42 & 15.8 \\
\hline Poor vendor support & EPR vendor support is poor. & 30 & 11.3 \\
\hline Maintenance fee & Maintenance fee of ERP is high. & 62 & 23.3 \\
\hline Upgrading & Cost for upgrading ERP is high. & 46 & 17.3 \\
\hline Annual op cost & $\begin{array}{l}\text { Annual operation cost of ERP is } \\
\text { high. }\end{array}$ & 46 & 17.3 \\
\hline Interface systems & $\begin{array}{l}\text { The implementation of an } \\
\text { interface between systems is costly. }\end{array}$ & 24 & 9.0 \\
\hline Better package & There are better packages. & 10 & 3.8 \\
\hline
\end{tabular}

\section{RESUlt OF HYPOTHESES}

Testing the efficacy of the structural equation model was conducted by AMOS 20, and the major results of analysis are shown in Figure 2, Figure 3, and Figure 4, respectively. The path diagram highlights the structural relationships. In this diagram, the measured variables are enclosed in boxes, latent variables are circled, and arrows connecting two variables represent relations, and open arrows represent errors. When SEM is used to verify a theoretical model, a greater goodness of fit is required for SEM analysis [6]; the better the fit, the closer the model matrix and the sample matrix.

By means of various goodness-of-fit indexes, including the comparative fit index (CFI) [2], the Tucker-Lewis Index (TLI) [25], Incremental Fit Index (IFI) [4], and the root mean squared error of approximation (RMSEA) [5], the estimated matrix can be evaluated against the observed sample covariance matrix to determine whether the hypothesized model is an acceptable representation of the data. In general, fit indexes (i.e., CFI, TLI, IFI) above 0.90 signify good model fit. RMSEA values lower than 0.08 
signify acceptable model fit, with values lower than 0.05 indicative of good model fit [5]. Since all of our indexes satisfy the cut-off values, our results are regarded as acceptable.

TABLE II. CORRELATION MATRIX SAMPLE

\begin{tabular}{|c|c|c|c|c|c|c|c|c|}
\hline & Gap & No fit & $\begin{array}{l}\text { Poor vendor } \\
\text { support }\end{array}$ & $\begin{array}{c}\text { Mentainance } \\
\text { fee }\end{array}$ & Upgrading & $\begin{array}{c}\text { Annual op } \\
\text { cost }\end{array}$ & $\begin{array}{c}\text { Interface } \\
\text { systems }\end{array}$ & $\begin{array}{c}\text { Better } \\
\text { package }\end{array}$ \\
\hline Gap & 1.00 & $0.35^{* * * *}$ & $0.34^{* * * *}$ & $0.18 * * *$ & -0.02 & $0.20^{* * * *}$ & $0.25^{* * * *}$ & $0.11^{*}$ \\
\hline No fit & $0.35^{* * * *}$ & 1.00 & $\overline{0.17^{* * * *}}$ & $0.13^{* *}$ & 0.02 & 0.05 & $0.12^{*}$ & 0.08 \\
\hline Poor vendor support & $0.34^{* * * *}$ & $0.17^{* * * *}$ & 1.00 & $0.31^{* * * *}$ & $0.12^{* * *}$ & $0.34^{* * * *}$ & $0.26^{* * * *}$ & 0.05 \\
\hline \begin{tabular}{|l} 
Mentainance fee \\
\end{tabular} & $0.18^{* * * *}$ & $0.13^{* *}$ & $0.31^{* * * *}$ & 1.00 & $0.45^{* * * *}$ & $0.57^{* * * *}$ & $0.26^{* * * *}$ & 0.08 \\
\hline Upgrading & -0.02 & 0.02 & $0.12^{* *}$ & $0.45^{* * * *}$ & 1.00 & \begin{tabular}{|l}
$0.45^{* * * *}$ \\
\end{tabular} & $0.31^{* * * *}$ & $0.12^{* * *}$ \\
\hline \begin{tabular}{|l} 
Annual op cost \\
\end{tabular} & $0.20^{* * * *}$ & 0.05 & $0.34^{* * * *}$ & $0.57 * * *$ & $0.45^{* * * *}$ & 1.00 & $0.38^{* * * *}$ & 0.07 \\
\hline Interface systems & $0.25^{* * * *}$ & $0.12^{*}$ & $0.26 * * *$ & $0.26 * * *$ & $0.31^{* * * *}$ & $0.38^{* * * *}$ & 1.00 & 0.08 \\
\hline Better package & $0.11^{*}$ & 0.08 & 0.05 & 0.08 & $0.12 *$ & 0.07 & 0.08 & 1.00 \\
\hline
\end{tabular}

A. Difficulties during the Definition Phase

The followings are results of hypotheses for the Definition Phase (see figure 2).

$\mathrm{H}-1$ : Difficulties in Information System is significantly positively affecting Project Supporter.

H-2: Difficulties in Project Supporter is significantly positively affecting Project Organization.

H-3: There is no significant relationship between Project Organization and Information System.

H-4: Difficulties in Information System is not affecting each of Definition Phase at all.

H-5: Difficulties in Project Supporter is significantly positively affecting each of Definition Phase.

H-6: Project Organization is negatively affecting each of Definition Phase, but not statistically significant.

B. Difficulties during the Design and Development Phase

The followings are results of hypotheses for the Design and Development Phase (see figure 3).

H-1: Difficulties in Information System is significantly positively affecting Project Supporter.

H-2: Difficulties in Project Supporter is significantly positively affecting Project Organization.

$\mathrm{H}-3$ : There is positive relationship between Project Organization and Information System, but not statistically significant.

H-4: Difficulties in Information System is positively affecting each of Design and Development Phase, but not statistically significant.

H-5: Difficulties in Project Supporter is positively affecting each of Design and Development Phase, but not statistically significant.

H-6: Project Organization is negatively affecting each of Design and Development Phase, but not statistically significant.

\section{Difficulties during the ERP Implementation Phase}

The followings are results of hypotheses for the ERP Implementation Phase (see figure 4).

$\mathrm{H}-1$ : Difficulties in Information System is significantly positively affecting Project Supporter.

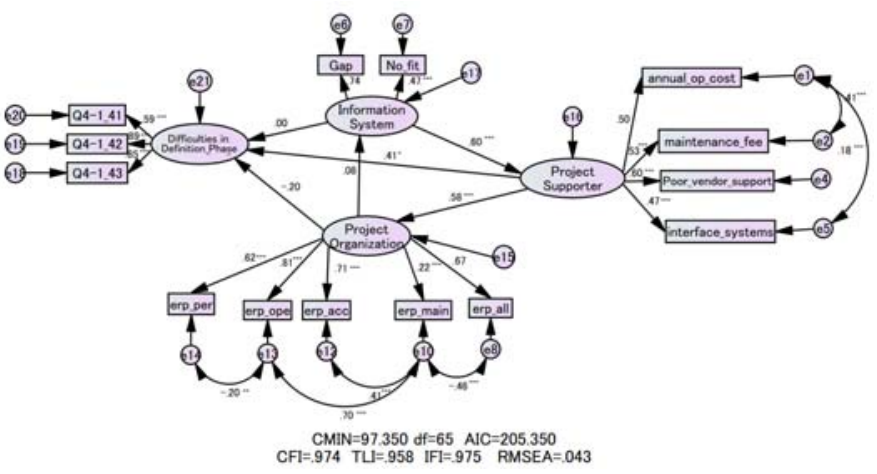

Figure 2. Difficulties during Definition

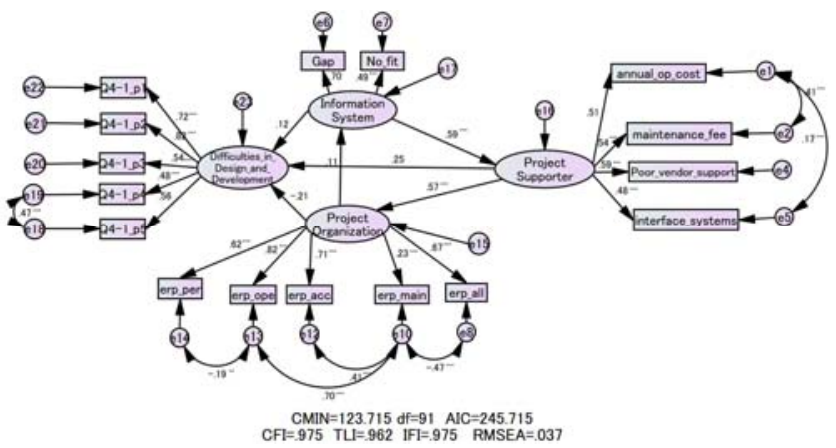

Figure 3. Difficulties during the Design and Development Phase

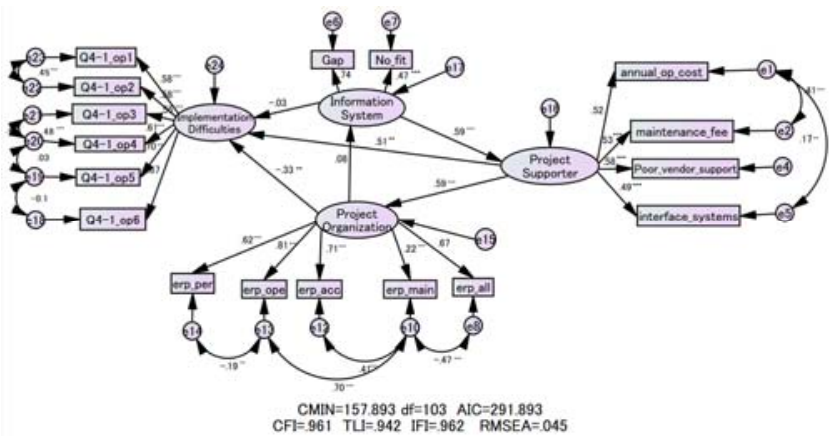

Figure 4. Difficulties during the ERP Implementation Phase.

H-2: Difficulties in Project Supporter is significantly positively affecting Project Organization.

H-3: There is no relationship between Project Organization and Information System.

$\mathrm{H}-4$ : Difficulties in Information System is negatively affecting each of ERP Implementation Phase, but not statistically significant.

H-5: Difficulties in Project Supporter is positively significantly affecting each of ERP Implementation Phase.

H-6: Project Organization is negatively affecting each of ERP Implementation Phase, but not statistically significant. 


\section{CONCLUSIONS AND MANAGERIAL IMPLICATION}

After analyzing the literature on IT failures with data from 266 ERP-user, this paper presents a framework and empirical analyses for assessing difficulties and factors lead to Enterprise Resource Planning (ERP) systems failure in Japan.

The results of the SEM model show that difficulties in Information System (gap and no fit) is significantly positively related to Project Supporter (annual op cost, maintenance fee, poor vendor support, interface system), and their Project Supporter is significantly positively related to Project Organization.

Project Supporter is significantly and positively related to Difficulties in the Definition Phase and in the ERP Implementation Phase, but not significantly related to the Design and Development Phase. Furthermore, difficulties in the Information System are not related to difficulties in any phases at all.

The results imply that the managerial implication for ERP vendors; lowering annual operating cost, maintenance fee, fees associated in interface systems is for one thing and improving vendor support for another, will reduce some difficulties in ERP implementation. Since this survey has been conducted every year, we would like to further investigate a relationship between ERP implementation and difficulties in Japan.

\section{ACKNOWLEDGMENT}

This work was supported in part by a JSPS Grant-inAid for Scientific Research in Japan (24530425). We would appreciate Impress Japan and ERP Forum in Japan for providing us their variable data.

\section{REFERENCES}

[1] D. Aloini, , R. Dulmin, and V. Mininno, "Risk management in ERP project introduction: review of the literature," Information \& Management, 44(6), 2007, pp. 547-567.

[2] P.M. Bentler, "Comparative fit indexes in structural models," Psychological Bulletin, 1990, pp. 238-246.

[3] P. Bingi, M. K. Sharma, and J. K. Godla, "Critical issues affecting an ERP implementation,” Information Systems Management, 16(3), 2001, pp. 7-14.

[4] K. A. Bollen, "A new incremental fit index for general structural equation models,” Sociological Methods and Research, 17, 1989, pp. 303-316.

[5] M. W. Browne, and R.Cudeck, "Alternative ways of assessing model fit,” Sociological Methods and Research, 21, 1992, pp. 230-258.

[6] B.M. Byrne, Structural Equation Modeling Using AMOS. Basic Concepts, Applications, and Programming (2nd ed.), New York: Routledge, 2010.

[7] F. Calisir, and F. Calisir, "The relation of interface usability characteristics, perceived usefulness, and perceived ease of use to end user satisfaction with enterprise resource planning (ERP) systems," Computers in Human Behavior, 20(4), 2004, pp.505-515.
[8] T. Davenport, "Mission critical: realizing the promise of enterprise systems,” Harvard Business School Press, USA, 2000.

[9] G. B. Davis, Management Information Systems: Conceptual Foundations, Structure and Development, McGraw-Hill, New York, 1974.

[10] W.H. DeLone, and E.R.Mclean, "Information systems success: the quest for the dependent variable," Information Systems Research, 3(1), March 1992, pp. 60-95.

[11] W.H. DeLone, and E.R. Mclean, "The DeLone and McLean model of information systems success: A ten-year update," Journal of Management Information Systems, 19(4), Spring, 2003, pp. 9-30.

[12] S. Dezdar, and S. Ainin, "ERP systems implementation success: A study on Iranian organizations," International Journal of Current Research and Review, 3(5), 2011, pp. 78-100.

[13] M. J. Ginzberg, "Early diagnosis of MIS implementation failure: promising results and unanswered questions,” Management Science, 27( 4), 1981, pp. 459-478.

[14] C. Holsapple, Y. Wang, J. Wu, "Empirically testing user characteristics and fitness factors in ERP success" International Journal of Human-Computer Interaction, 19(3) , 2006, pp. 325-342.

[15] K. Lyytinen, and R. Hirschheim, "Information systems failures - a survey and classification of the empirical literature,” Oxford Surveys in Information Technology, 1987, pp. 257-309.

[16] M.L. Markus, and C. Tanis, "The enterprise system experience: from adoption to success,” In: Zmud, R. (ed.), Framing the Domains of IT Management: Projecting the Future through the Past, Pinnaflex Educational Resources Inc, Cincinnati, 2000.

[17] M. Martin, “An ERP Strategy,” Fortune, pp. 95-97. 2 February, 1998.

[18] M. Miyamoto, S. Kudo, and K. Iizuka, "Measuring ERP success: integrated model for user satisfaction and technology acceptance An empirical study in Japan," Proceedings of Economics Development and Research, 2012 International Conference on Business, Management and Governance (ICBMG2012), 57, 2012, pp. 86-91.

[19] E.W.T. Ngai, C.C.H.Law, and F.K.T. Wat, "Examining the critical success factors in the adoption of enterprise resource planning," Computers in Industry, 59 (6), 2008, pp. 548-564.

[20] C. Sauer, Why information systems fail: a case study approach. Alfred Waller Henley, 1993.

[21] C.J. Stefanou, "The selection process of ERP system," Proceedings of the Sixth Americas Conference on Information Systems (AMCIS 2000), 2000, pp. 988-991.

[22] C. Soh, and M.L. Markus, "How IT creates business value: a process theory synthesis," In Ariav, G. et al. (eds.) Proceedings of the 16th International Conference on Information Systems, Amsterdam, Netherlands, 1995

[23] C. Soh, S.S. Kien, and J. Tay-Yap, "Cultural fits and misfits: is ERP a universal solution?,” Communications of the ACM, 43, 2000, pp. 47-51.

[24] Y. Taguchi, "ERP user survey 2011 executive summary (English Version),” ERP Forum Japan, 2011.

[25] L. R. Tucker, and C. Lewis, "A reliability coefficient for maximum likelihood factor analysis,” Psychometrika, 38, 1973, pp. 1-10.

[26] J. H. Wu, and Y. M.Wang, "Measuring ERP success: the key-users' viewpoint of the ERP to produce a viable IS in the organization," Computers in Human Behavior, 23(3), 2007, pp. 1582-1596.

[27] M. Zviran, N. Pliskin, and R. Levin, "Measuring user satisfaction and perceived usefulness in the ERP context," Journal of Computer Information Systems, 45(3), 2005, pp. 43-52. 